\title{
Determination of anti-cancer and apoptotic effects of Tricholoma terreum, Tricholoma arvernense and Tricholoma imbricatum species
}

\author{
Ali Ozmen \\ Adnan Menderes University, Faculty of Arts and Sciences, Department of Biology \\ Central Campus, 09010 Efeler Aydin, Turkey \\ E-mail: aozmen@adu.edu.tr
}

Bu proje Adnan Menderes Üniversitesi Bilimsel Araştırma Projeleri Birimi tarafindan desteklenmiştir (FEF-12006)

\begin{abstract}
Macrofungi has been used for food and therapeutic purposes for centuries. In terms of their medicinal properties, the fungi contain a variety of polysaccharides, polysaccharide-protein complexes and secondary metabolites. The antimicrobial, antioxidant and anticancer effects are associated with these ingredients. As a cancer-associated fungus, Ganoderma lucidum is the best known in the world. On the other hand, anticancer activity and contents of many mushrooms were investigated. In the genus Tricholoma, T. matsutake is well known in Japan. The medicinal properties of this mushroom have been demonstrated. In this study Tricholoma terreum, Tricholoma arvernense and Tricholoma imbricatum from Turkey have been investigated for anticancer activity and apoptotic effects. Derived extracts from collected fungi were tested against HL 60 and MCF-7 human cancer cell lines. Antiproliferative effect were determined by using MTT method and determination of apoptotic cells was performed using Hoechst/Propidium iodide (HO/PI) double staining method. Different extracts from T.terreum, T. arvernense and T.imbricatum species inhibited $50 \%$ of the cells in the concentration range of $15-20 \mathrm{mg}$ / ml, especially in the HL-60 leukemia cell line and in apoptosis research with these extracts $T$. imbricatum methanol extract caused about $\% 60$ apoptotic cell death at the $40 \mathrm{mg} / \mathrm{ml}$ concentration.
\end{abstract}

Keywords: Apoptozis, Tricholoma, Cell culture

DOI: $10.7176 /$ JSTR/5-2-03

\section{Tricholoma terreum, Tricholoma arvernense ve Tricholoma imbricatum türlerinin antikanser ve apoptotik etkilerinin belirlenmesi}

\begin{abstract}
Özet
Makrofunguslar yüzyıllardan beri besin ve tedavi amaçlı kullanılmaktadırlar. Tıbbi özellikleri bakımından mantarlar çeşitli polisakkaritler, polisakkarit-protein kompleksleri ve sekonder metabolitler içermektedirler. Antimikrobiyal, antioksidan ve antikanser etkileri bu içerikler ile bağdaştırılmıştır. Kanser ile ilişkili mantar olarak Dünya'da en iyi bilinen Ganoderma lucidum'dur. Diğer taraftan birçok şapkalı mantarın antikanser aktivitesi ve içerikleri araştırılmıştır. Tricholoma cinsinden ise T. matsutake Japonya'da çok iyi bilinmektedir. Bu mantarın tıbbi özellikleri ortaya konmuştur. Bu çalışma kapsamında Türkiye'deki bulunan Tricholoma terreum, Tricholoma arvernense ve Tricholoma imbricatum türleri antikanser aktivite ve apoptotik etki bakımından araştırılmıştır. Toplanan mantarlardan elde edilen özütler HL 60 ve MCF-7 insan kanser hücre hatlarına karşı denenmiştir. Bölünmeyi inhibe edici etki MTT yöntemi ve apoptotik hücrelerin belirlenmesi Hoechst/Propidium iodide (HO/PI) ikili boyama yöntemi kullanılarak yapılmıştır. T.terreum, T. arvernense ve T.imbricatum türlerinden elde edilen farklı özütler özellikle HL-60 lösemi hücre hattında 15-20 mg/ml konsantrasyon aralığında hücrelerin \%50'sini inhibe etmiştir. Bu özütler ile yapılan apoptozis araştırmalarında ise T. imbricatum metanol özütü $40 \mathrm{mg} / \mathrm{ml}$ konsantrasyonda \%60'ın üzerinde apoptotik hücre ölümüne yol açmıştır.
\end{abstract}

Anahtar kelimeler: Apoptozis, Tricholoma, Hücre Kültürü

20 | P a g e

www.iiste.org 


\section{Giriş}

Makrofunguslar yüzyıllardan beri besin ve tedavi amaçlı kullanılmaktadırlar. Günümüzde makrofunguslar ile birçok bilim dalı değişik araştırmalar yapmaktadır. Başta ziraat olmak üzere biyoloji, gıda, eczacılık, çevre ve tıp bilim dallarında makrofunguslar ile çalışmalar yapılmakta ve yeni çalışmalar planlanmaktadır. En iyi bilinen tıbbi özelliklere sahip mantar olan Ganoderma lucidum (Reishi, Ling Zhi) Orta Asya'da 2000 yıldan daha uzun zamandır bilinmekte ve Çin'de ölümsüzlük mantarı olarak anılmaktadır. Uzak Doğu kültüründe yemek ve ilaç olarak kullanılan makrofunguslar üzerine yapılan çalışmalar günümüzde artarak devam etmektedir. Makrofungusların taşımış oldukları tıbbi özellikler üzerine yapılan çalışmalar bazı genel başlıklar altında toplanabilir. Bunlar kan basıncı kontrolü, antitümör özellik, bağışıklık sisteminin güçlendirilmesi, antimikrobiyal etki, antibiyotik etki, antioksidan özellik, anti-diabetik etki, anti-HIV aktivite, anti-obesitik aktivite, anti-viral etki ve anti-aging etki şeklinde sayılabilir.

Mantarlar besin değerleri ve tıbbi özelliklerinden dolayı insanlar tarafindan yaygın olarak tüketilmektedir. Bu mantarlar antioksidan ve antimikrobiyal özellik göstermektedirler. Ayrıca antikanser ve vücut savunma sistemi açısından zengin kaynaklar teşkil etmektedirler (Ganeshpurkar vd., 2010). Bu bakımdan mantarlardan elde edilen yeni kimyasallar çok daha önemli olacaklardır.

Antioksidan aktiviteye sahip doğal ürünler Reaktif Oksijen Türlerine karşı savunma mekanizmasını arttırırlar. Bu açıdan beslenmede antioksidanların tüketilmesi oksidatif hasarı azaltmaktadır. Birçok mantar türü araştırıcılar tarafından antioksidan içerik bakımından ele alınmıștır ve antioksidan bileşikler tanımlanmıştır. Bunlar fenolik bileşikler, tokoferoller, askorbik asit ve karotenoidlerdir (Ferreira vd., 2009). Doğada yetişen mantarlar insan sağlı̆̆ını desteklemek açısından beslenmede kullanılmalıdır.

Breene (1990) birkaç mantar türünün ya da ekstraktlarının antitümör aktivitesinin olduğunu bildirmiștir. Bu türler: Agaricus bisporus, Auricularia auricula, Collybia confluens, Coriolus versicolor, Flammulina velutipes, Ganoderma applanatum, G. lucidum, Lentinus edodes, Pholiota nameko, Pleutorus ostreatus, Schizophyllum commune, Tremella fuciformis, Tricholoma matsutake ve Volvariella volvacea.

Bu çalışma kapsamında araştırılmış olan Tricholoma mantarları ile ilgili ilk yazılı bilgilere çok eski çăglardan beri bu mantar grubuna önem veren Japonya'da rastlanılmaktadır. Milattan sonra 759 yıllarında yazılmış bir şiirde Tricholoma mantarlarının (Japonya'daki ismi "Matsutake") önemli ve insan sağlı̆̆ı açısından faydalı bir gıda maddesi olduğundan övülerek bahsedilmektedir (Hosford vd., 1997).

Literatür incelendiğinde Tricholoma türlerinin etkinliğini ortaya koyabilecek çalışmalar mevcuttur. $\mathrm{Bu}$ çalışmalar özellikle antioksidan ve antitümör kapsamında yer almaktadır. Mantarların genel anlamda antioksidan bileşikler içerdikleri günümüzde artık bilinmekle beraber bu konuda yeni ve daha etkili bileşikler veya antioksidan kapasitesi daha yüksek mantarlar belirlemek için çalışmalar sürdürülmektedir. Literatüre bakıldığında; T. mongolicum'dan elde edilen polisakkaritlerin iyi düzeyde antioksidan kapasitelerinin olduğu bildirilmiştir (You vd., 2014). Bir başka tür olan T. crassum türünün sıcak su özütünden izole edilen bir glukanın yapısı aydınlatılmış ve hücrelerde biyolojik olarak oksidatif strese neden olan lipit peroksidasyonunu iyi düzeyde inhibe ettiği bulunmuştur (Samanta vd., 2013). T. lobayense mantarından elde edilen polisakkaritlerin güçlü antioksidan kapasiteye sahip olduğu bulunmuştur (Wang vd., 2012). T. matsutake çeşitli fenolikler, flavonoidler, alkolodiler, steroidler ve steroller içermektedir. Antioksidan kapasite ve fenolik-flavonoid içeriği bakımından mantarların etkinliği ortaya konulmuştur (Lim vd., 2007).

Diğer taraftan Tricholoma türlerinden bazı polisakkarit peptit kompleksleri elde edilmiştir ve bunların özellikle fare tümörlerindeki etkinlikleri çalışılmıştır. Bu çalı̧̧alardan bir tanesinde elde edilen bu tip bir kompleksin immün sisteme ait T-hücrelerini uyararak tümöre karşı bir immün düzenleme sağladığ1 ve yine farelerde Sarkoma 180 hücrelerini inhibe ettiği bulunmuştur (Wang vd., 1995). T. giganteum mantarı yenilebilen büyük bir mantardır. Bu mantarın meyvesinden 4 farklı polisakkarit izole edilmiş ve farelere aktarılan Sarkoma 180 tümörüne karşı denenmiştir. Burada çeşitli fraksiyonların farelerde oluşan tümörlerde gerileme sağladığı gösterilmiştir (Mizuno vd., 1995). T. mongolicum'un misel kültürlerinden yeni bir polisakkarit-peptit kompleksi izole edilmiştir. Bu kompleks farelere implante edilen Sarkoma 180 hücrelerinin bölünmelerini inhibe etmiştir (Wang vd., 1996). T. lobayense mantarından elde edilen bir polisakkarit-protein kompleksi farelerde antitümör aktivite göstermiş̧ir. Bunun dışında HL-60, PU 51.8 ve H3B tümör hücrelerine karşı 30-60 $\mu \mathrm{g} / \mathrm{ml}$ aralı̆ı̆nda sitotoksik bulunmuştur (Liu vd., 1996). T.mongolicum'dan elde edilen 2 adet lektin çeşitli fare tümör hücre hatlarında antitümöral aktivite göstermiştir (Wang vd., 1995, Li vd., 2008). Başka çalışmalar elde edilen bu lektinlerin aynı zamanda farelerde oluşan tümörleri inhibe ettiğgini göstererek antiproliferatif aktivitelerini desteklemektedir (Pena vd., 2009). Yapılan çalışmalar mantar özütlerinin ras aracılı̆̆ıyla yürütülen sinyalizasyon yolunu etkiledikleri ve antikanser etkilerini bu şekilde gösterdikleri sonucuna varılmıştır (Hsiao vd., 2004).Yenilebilir bir mantar olan T. mongolicum mantarından yeni bir lakkaz izole edilip kanser hücrelerine karşı etkinliği çalışılmıştır. Karaciğer (HepG2) ve Meme (MCF-7) kanserlerinin hücre

21 I P a g e 
hatlarına karşı 0,3-5 $\mu \mathrm{M}$ aralığında denenmiştir. Konsantrasyon artışına bağlı olarak hücreleri \%8-92 aralı̆̆ında öldürürken normal insan epitelyum hücrelerine (WRL-68) karşı $1 \mathrm{mM}$ konsantrasyonun üzerinde bile etkili olmamıştır (Miao vd., 2010). T. matsutake metanol özütünün HSC-2 insan oral kanserindeki etkileri araştırılmıştır. Yapılan bu çalışmada mantar özütünün hücrelerin bölünmesini inhibe ettiği ve apoptozisi uyardığı bulunmuştur (Shin vd., 2012). T. giganteum'dan elde edilen $\% 80$ 'lik etanol özütünün Erlih asit tümörüne karşı etkinliği çalışılmıştır (Chatterjee vd., 2013). T. matsutake'den elde edilen polisakkaritlerin antitümör aktiviteleri HepG2 (Karaciğer) ve A549 (Akciğer) kanser hücre hatları kullanılarak MTT yöntemi ile araştırılmıştır. Bu çalışmada izole edilen polisakkaritlerden bir tanesinin hem antioksidan kapasitesi hem de her iki hücre hattına karşı etkinliği oldukça yüksek bulunmuştur (You vd., 2013). T. terreum isimli mantarın meyvelerinden "terreumols" diye adlandırılan 4 adet yeni terpenoid elde edilmiştir. Bunların sitotoksik aktiviteleri 5 adet insan kanser hücre hattında çalıșılmıștır ve etkileri cisplatin isimli kemoterapik ajan ile karşılaştırılmıştır. Özellikle akciğer, meme ve kolon kanseri hücrelerinde pozitif kontrol olarak kullanılan cisplatin kadar etkili bulunmuştur (Yin vd., 2013).

Yapılan bu çalışma kapsamında Türkiye'den toplanmış olan Tricholoma terreum, Tricholoma arvernense ve Tricholoma imbricatum türlerinin kanser hücre hatları üzerindeki durdurucu ve apoptotik etkileri araştırılmıştır. Tricholoma türlerinden ekstraktlar elde edilip HL-60 ve MCF-7 hücre hatlarına uygulanmıştır. Bunların antiproliferatif etkinliği ve apoptotik potansiyelleri ortaya konmuştur.

\section{2- Materyal ve Yöntem}

\section{1-Mantarlarin toplanmasi}

Çalışmada kullanılmak üzere seçilen mantarlar Çizelge 1.'de belirtilen tarihlerde belirtilen yerlerden Prof. Dr. Mesut KIRMACI ile birlikte toplanmıştır ve araziden geldikten hemen sonra Prof. Dr. Mesut KIRMACI tarafindan tayin edilmiştir. Daha sonra dinlendirilmiş çeşme suyu ile yıkanarak paketlenmiş ve denemeler yapılıncaya kadar $-80{ }^{\circ} \mathrm{C}$ 'de saklanmıştır.

Çizelge 1. Mantarlara ilişkin lokaliteler ve toplanma tarihleri

\begin{tabular}{|l|l|l|}
\hline Takson adı & $\begin{array}{l}\text { Toplanma } \\
\text { tarihi }\end{array}$ & Bulundukları yer \\
\hline $\begin{array}{l}\text { Tricholoma terreum } \\
\text { Syn: Tricholoma } \\
\text { myomyces }\end{array}$ & Mayıs-Ekim & $\begin{array}{l}\text { KONYA-BOZKIR Sorkun-Dere yol kenarı, 1280 m } \\
\text { DENIZLİ-ÇAMELİ, Bıçakçı köyü, çam ormanı }\end{array}$ \\
\hline Tricholoma arvernense & Ekim & DENİZLİ-ÇAMELİ, Sofular köyü, çam ormanı \\
\hline Tricholoma imbricatum & Ekim & ANTALYA-Akseki, zamona mevkii, çam ormanı 1500 m \\
\hline
\end{tabular}

\section{2-Mantarlardan ekstraktlarin elde edilmesi}

Ekstraksiyon için Petrol eteri, Etil asetat, Diklormetan ve Metanol kullanılmıştır. $-80{ }^{\circ} \mathrm{C}$ 'de dondurulmuş olan materyal liyofilizatör yardımı ile kurutulmuştur. Mantarların liyofilizasyon öncesi yaş ağırlıkları ve liyofilizasyon sonrası kuru ağırlıkları belirlenmiştir. Her bir mantarın kuru örneklerinden $10 \mathrm{gr}$ alınarak soksalet, çalkalayıcı ve evaporatör yardımıyla; Petrol eteri, Etil asetat, Diklormetan ve Metanol ekstraktları hazırlanmıştır. Ekstraksiyon için kullanılmış olan bu çözücüler polarite özellikleri göz önünde bulundurularak seçilmiştir. Mantar ekstraktları sitotoksik değerlendirmede kullanılmak üzere $\% 100$ etanol içerisinde çözdürülmüştür. $\mathrm{Bu}$ aşamadaki çalışmalar; $-80{ }^{\circ} \mathrm{C}$ 'den çıkarılan ekstraktların aktivitelerinin kaybolmasını engellemek amacıyla buz üzerinde yapılmıştır. Ekstraktların üzerine bir defada $500 \mu \mathrm{l}$ olmak üzere etanol ilavesi yapılmış ve her ilaveden sonra sonikatör yardımı ile ekstraktlar çözdürülmüştür. Ekstraktları çözmek için kullanılabilecek olan maksimum etanol miktarı HL60 hücreleri ile bir ön deneme yapılarak belirlenmiştir. Bu ön denemeye ilişkin sonuçlara göre esas denemede kullanılacak alkol konsantrasyonunun maksimum \%0,12 - \%0.46 değerleri arasında kalması gerektiği belirlenmiştir. Daha yüksek miktarlarda alkol kullanıldığında hücrelerin normal çoğalmaları etkilenmektedir.

Kullanılan çözücü miktarlarına bağlı olarak elde edilen çözünmüş mantar ekstraktlarının yoğunluğu, kuru ağırlık göz önünde bulundurularak $\mathrm{g} / \mathrm{ml}$ cinsinden stok değer olarak hesaplanmıştır. Her mantar türünden 10 gr kuru ağırlık kullanılmış olması nedeniyle $10 \mathrm{gr} / \mathrm{ml}$ stok çözeltiler elde edilmiştir. Sitotoksik değerlendirmede kullanılmak üzere çözünmüş ekstraktlar soğutuculu santrifüjde $+4{ }^{0} \mathrm{C}$ 'de, $12.000 \mathrm{rpm}$ 'de $5 \mathrm{dk}$ santrifüjlenmiştir. Buradan elde edilen süpernatantlar başka bir tüpe aktarılarak geriye kalan pelletler de $-80^{\circ} \mathrm{C}$ 'de saklanmıştır. Sitotoksik değerlendirmede süpernatantlar kullanılmıştır. 


\section{3-Hücre kültürü}

\subsection{1-Hücrelerin ve kültür ortamlarının temini}

HL-60 ve MCF-7 hücre hatları ATCC (American Type Culture Collection; ATCC)'den alınmıştır ve GIBCO (Invitrogen Co.)'nun standart hücre kültürü ortamlarında büyütülmüştür. Kültür ortamına yapılan ilaveler de (Fetal Calf Serum, L-Glutamin, Streptomisin-Pensilin, Non essential aminoasitler) GIBCO'dan alınmıştır. Apoptotik etkiyi belirlemek için Hoechst 33258 ve Propidium Iodide SIGMA (Sigma-Aldrich Co.)'dan alınmıştır.

\subsection{2-Hücrelerin çoğaltılması ve ekstrakt uygulamaları}

Hücreler ml'de 10.000-100.000 hücre aralığında kültür şişesinde çoğaltılmış ve mantar ekstraktları artan konsantrasyonlarda $(10,20$ ve $40 \mathrm{mg} / \mathrm{ml})$ 24, 48 ve 72 saat olmak üzere uygulanmıştır. Kontrol ve uygulama gruplarındaki canlı hücreler MTT [3-(4,5-dimethyl thiazol-2-yl)-2,5-diphenyl tetrazolium bromide] boyama yönteme ile belirlenmiştir. Çözeltinin ölçümü spektrofotometre ile $590 \mathrm{~nm}$ dalga boyunda yapılmıştır.

\subsection{3-Bölünen hücre oranının hesaplanması}

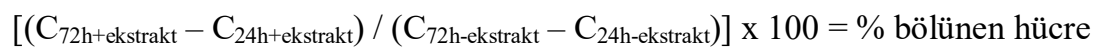

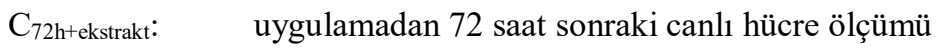

$$
\begin{aligned}
& \mathrm{C}_{24 h+e k s t r a k t} \text { uygulamadan } 24 \text { saat sonraki canlı hücre ölçümü } \\
& \text { C72h-ekstrakt: } \quad \text { ekstrakt uygulaması olmadan } 72 \text { saat sonraki canlı hücre ölçümü }
\end{aligned}
$$

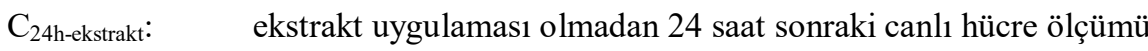

Ham veriler ilgili çizelgeden exel dosyasına aktarılıp bölünen hücre oranının hesaplanması yukarıdaki formüller ile yapılmıştır. Bütün denemeler 3 tekrarlı yapılmıştır.

\section{4-Apoptozis ve Nekrozis yöntemi}

Apoptotik ve nekrotik etkiyi belirlemek için; hücreler kültür şişelerinde düşük yoğunlukta çoğaltılmıştır ve bölünmeyi engelleyici aktivite verilerine göre etkili bulunan seçilmiş mantar ekstraktlarının etkili konsantrasyonları ile muamele edilmiştir. Hücreler HO/PI (Hoechst 33258 / Propidium Iodide) yöntemiyle boyanarak apoptotik ve nekrotik etki gösteren ekstraktlar belirlenmiştir (Grusch, vd, 2002, Huettenbrenner, vd.,2003). Ekstrakt uygulaması sonucunda hücreler mikroskop altında gözlemlenmiş ve sayılmıştır. Kontrol grubu ile kıyaslamalı olarak grafikler hazırlanıp sunulmuştur. Apoptozis ve nekrozis oranları kontrol grubundaki sayılarına karşılık uygulama gruplarında \% artış (\%kontrol) olarak ifade edilmiştir.

\section{5- Istatistiki de ğerlendirme}

GraphPad 4.0 analiz programı ile kontrol ve uygulama grupları arasındaki farklılıklar standart hataları içeren grafiklere aktarılmıştır. Kontrol grubundaki canlı hücreler ile uygulama gruplarındaki canlı hücreler ayrı sütunlarda gösterilmiş ve 3'lü tekrarlar halinde elde edilen verilerdeki standart hatalar hesaplanmıştir.

\section{3-Bulgular}

Çalışma 3 temel aşamada gerçekleştirilmiştir. Bu aşamalar; materyalin toplanması ve ekstraksiyonu, bölünmeyi engelleyici aktivitenin belirlenmesi ve apoptotik etkinin belirlenmesi aşamalarıdır. Bu kapsamda toplanan mantarlardan özütler elde edilmiştir. Devamında, bölünmeyi engelleyici aktiviteler HL-60 insan lösemi hücre hattı ve MCF-7 meme kanseri hücre hattı kullanılarak belirlenmiştir ve en etkili özüt tiplerinin hücrelerin \%50'sini öldüren konsantrasyonları seçilmiştir. Seçilen özütler ile apoptotik etkiler belirlenmiştir. Çalışmadan elde edilen bulgular yukarıda belirtilen sıralamaya göre aşağıda sunulmaktadır.

\section{1- Bölünmeyi engelleyici aktivite bulguları}

HL-60 ve MCF-7 hücreleri yöntemde de belirtildiği gibi ml'de 10.000-100.000 hücre olacak şekilde kültür şişesinde çoğaltılmıştır ve mantar ekstraktları artan konsantrasyonlarda (10, $20 \mathrm{ve} 40 \mathrm{mg} / \mathrm{ml}) 24$, 48 ve 72 saat olmak üzere her iki hücre hattına uygulanmıştır. Daha sonra canlı hücreler MTT yöntemi ile incelenerek hücrelerin \%50'sini öldüren konsantrasyon $\left(\mathrm{I}_{\mathrm{p}} \mathrm{C}_{50}\right)$ belirlenmiştir. Denemeler sonucu elde edilen etkili ekstrakt tiplerine ait proliferasyon verileri Şekil 1'de her bir tür için $(a-c)$ sütün grafikler şeklinde sunulmuştur. Her bir türün bölünmeyici engelleyici aktivitesi ile ilgili bulgular Şekillerin altında

23 | P a g e 
açıklama olarak verilmiştir. Proliferasyon çalışmaları aşamasında bu mantarlara ait etkili özüt tipleri belirlenmiştir. Bu aşamada yapılan çalışma ile apoptozis denemelerinde kullanılacak olan özüt tipleri ve konsantrasyonları kararlaştırılmışıı. Apoptozis denemelerine ilişkin veriler Şekil 2'de yer almaktadır.

Şekil 1. Mantarlardan elde edilen etkili özütlerin artan konsantrasyonlarda uygulanması sonucunda elde edilen proliferasyon verileri

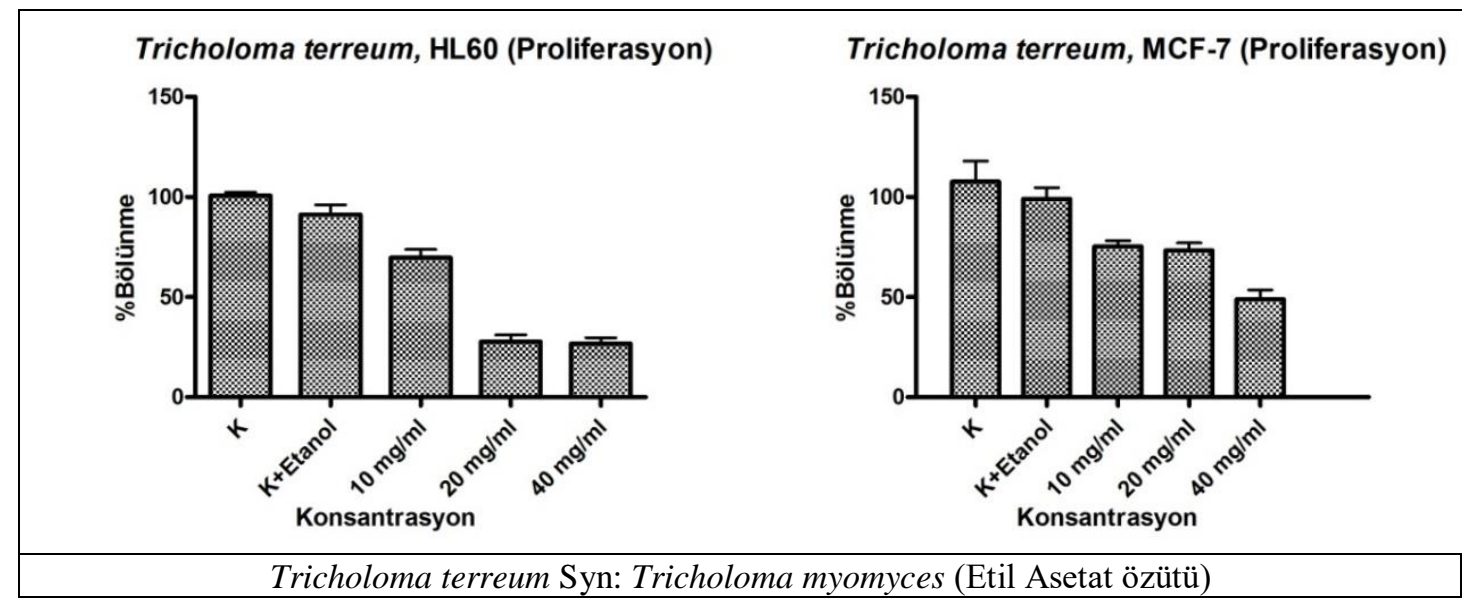

Şekil 1a- Tricholoma terreum Syn: Tricholoma myomyces mantarına ait özütler artan konsantrasyonda HL-60 ve MCF-7 hücre hatlarına uygulanmıştır. $10-40 \mathrm{mg} / \mathrm{ml}$ aralığında denenmiş olan farklı özüt tiplerinden etil asetat özellikle HL-60 hücre hattına karşı iyi düzeyde etkili bulunmuştur. Burada etil asetat özütünün $\mathrm{HL}-60$ hücre hattındaki $\mathrm{I}_{\mathrm{p}} \mathrm{C}_{50}$ değeri yaklaşık $15 \mathrm{mg} / \mathrm{ml}$ olarak hesaplanmıştır. MCF-7 hücre hattında bu değer ancak $40 \mathrm{mg} / \mathrm{ml}$ konsantrasyonda yakalanmıştır. Bu mantara ait etil asetat özütü HL-60 hücre hattında daha etkili bulunmuştur.

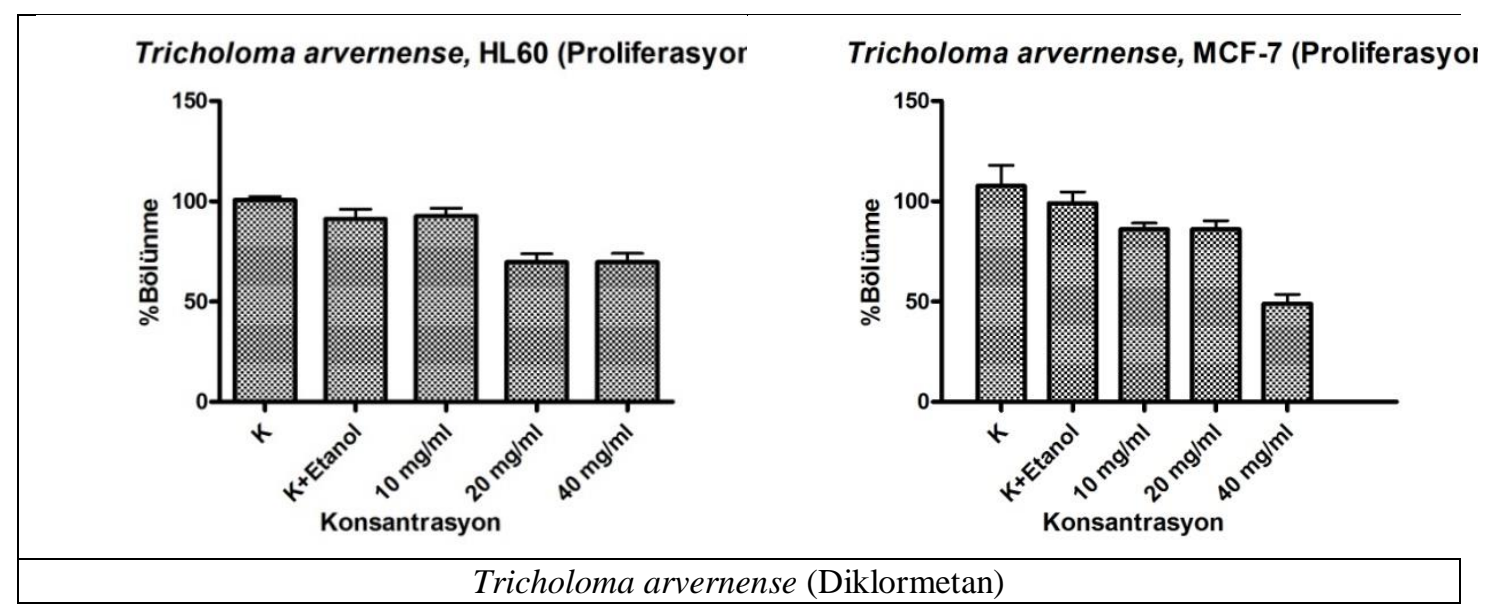

Şekil 1b- Tricholoma arvernense mantarına ait özütler artan konsantrasyonda HL-60 ve MCF-7 hücre hatlarına uygulanmıştır. 10-40 mg/ml aralığında denenmiş olan farklı̈ özüt tiplerinden diklormetan sadece MCF-7 hücre hattına karşı düşük düzeyde etkili bulunmuştur. Burada diklormetan özütünün MCF-7 hücre hattındaki $\mathrm{I}_{\mathrm{p}} \mathrm{C}_{50}$ değeri $40 \mathrm{mg} / \mathrm{ml}$ olarak hesaplanmıştır. Şekilden de anlaşılacağ mantardan elde edilen özütler uygun konsantrasyonlarda etkili bulunmamıştır. 


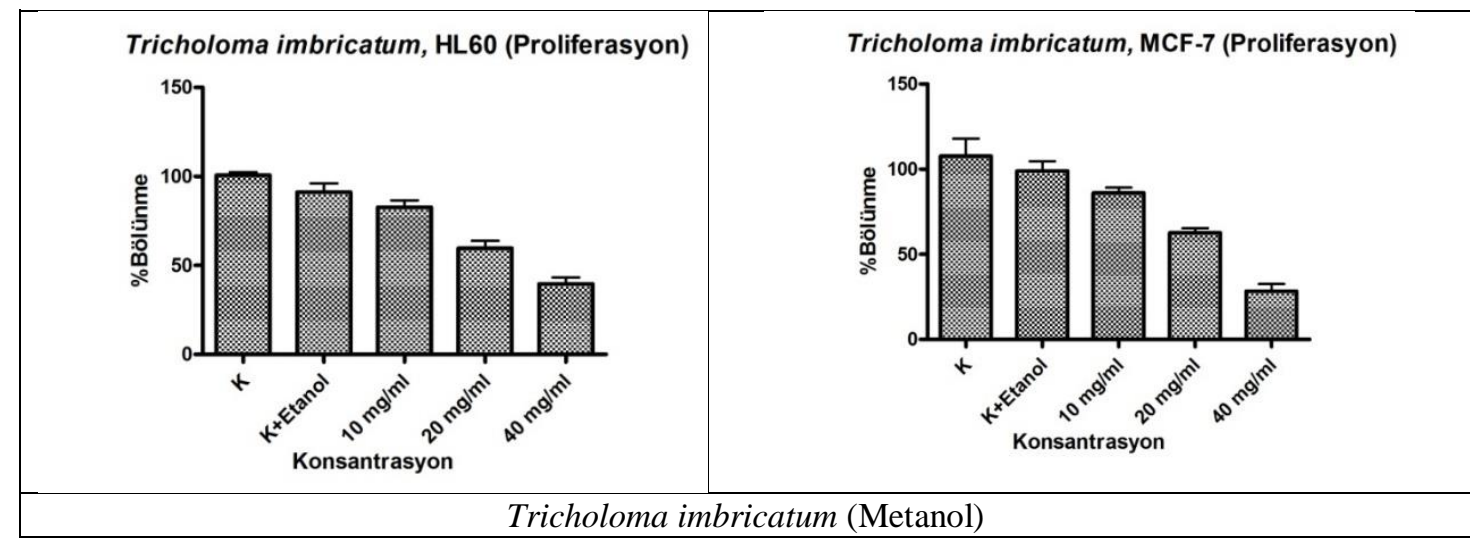

Şekil 1c- Tricholoma imbricatum mantarına ait özütler artan konsantrasyonda HL-60 ve MCF-7 hücre hatlarına uygulanmıştır. 10-40 mg/ml aralığında denenmiş olan farklı özüt tiplerinden metanol her iki hücre hattına karşı 20-40 mg/ml aralığında etkili bulunmuştur. Burada metanol özütünün HL-60 hücre hattındaki $\mathrm{I}_{\mathrm{p}} \mathrm{C}_{50}$ değeri yaklaşık $30 \mathrm{mg} / \mathrm{ml}$ olarak hesaplanmıştır. MCF-7 hücre hattında da bu değer yaklaşık $30 \mathrm{mg} / \mathrm{ml}$ olarak belirlenmiştir.

Şekil 2. Seçilen özütlerin etkili konsantrasyonlarının uygulanması sonucunda elde edilen apoptozis verileri

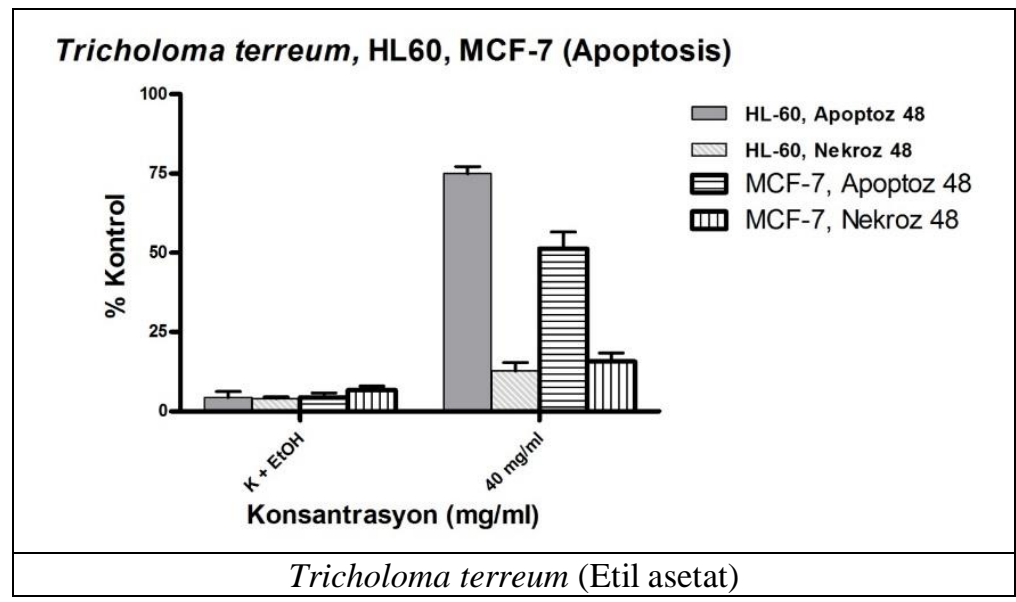

Şekil $2 a$ - Tricholoma terreum mantarına ait seçilen etil asetat özüt tipi $40 \mathrm{mg} / \mathrm{ml}$ konsantrasyonda HL60 ve MCF-7 hücrelerine uygulanmıştır. Bu özüt tipinin 48 saatlik apoptotik etkisi HO/PI boyama yöntemi ile belirlenmiştir. Elde edilen sonuçlara göre nekrotik etki ile birlikte 48 saat apoptozis verileri özellikle HL-60 hücre hattında yüksek bulunmuştur.

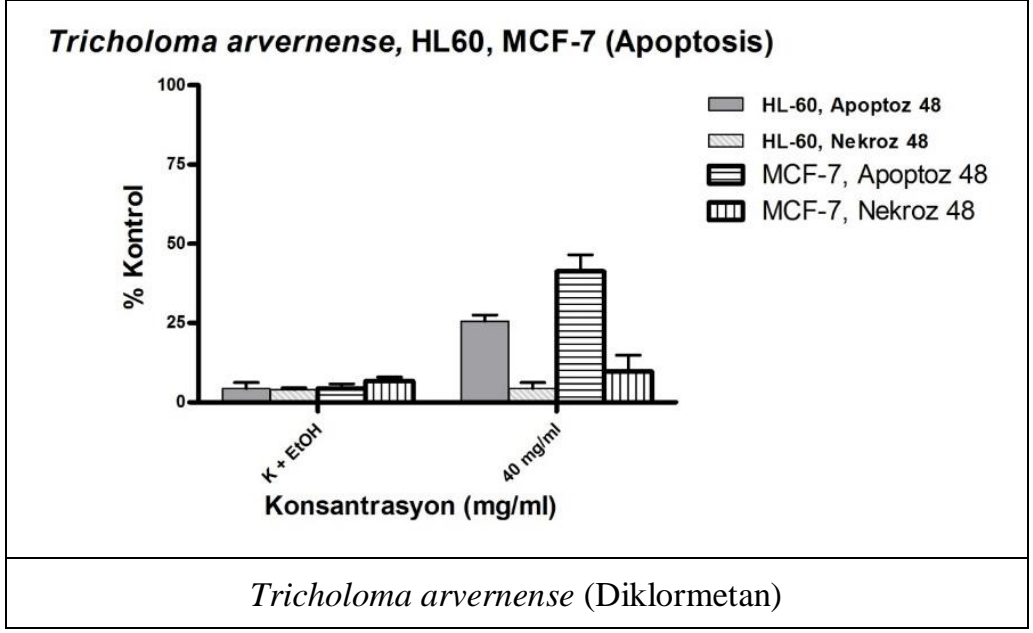


Şekil $2 b$ - Tricholoma arvernense mantarına ait seçilen diklormetan özüt tipi $40 \mathrm{mg} / \mathrm{ml}$ konsantrasyonda HL-60 ve MCF-7 hücrelerine uygulanmıştır. Bu özüt tipinin 48 saatlik apoptotik etkisi HO/PI boyama yöntemi ile belirlenmiştir. Çalışma sonucunda MCF-7 hücre hattında nekrotik hücreler ile birlikte çok iyi sayılamayacak düzeyde apoptotik hücre gözlenmiştir.

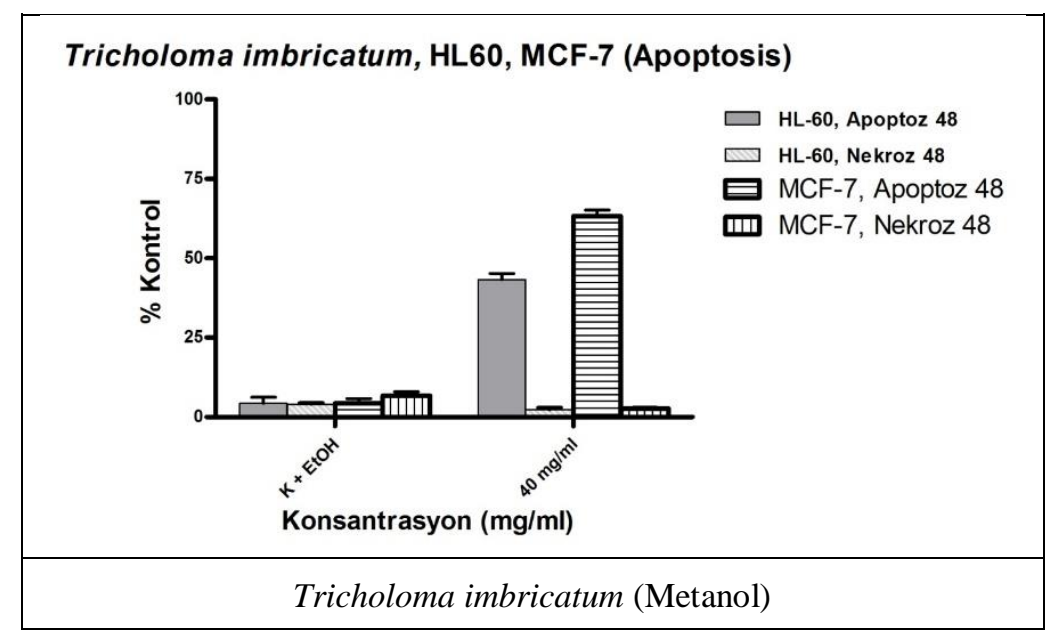

Şekil 2c-Tricholoma imbricatum mantarına ait seçilen metanol özüt tipi $40 \mathrm{mg} / \mathrm{ml}$ konsantrasyonda HL60 ve MCF-7 hücrelerine uygulanmıştır. Bu özüt tipinin 48 saatlik apoptotik etkisi HO/PI boyama yöntemi ile belirlenmiştir. Çalışma sonucunda her iki hücre hattında çok az miktarda nekrotik hücrenin yanında kontrole gore \%50-60 aralığında apoptotik hücrelerin arttığı gözlenmiştir.

\section{2- Apoptozis yöntemine iliş̧kin bulgular}

Apoptotik ve nekrotik etkiyi belirlemek için; HL-60 ve MCF-7 hücreleri kültür şişelerinde düşük yoğunlukta çoğaltılmıştır ve bölünmeyi engelleyici aktivite verilerine göre etkili bulunan seçilmiş mantar ekstraktlarının etkili konsantrasyonları ile muamele edilmiştir. Bu amaçla, HL-60 ve MCF-7 hücreleri 10.000-100.000/ml yoğunluk aralığında well-platelere aktarılmıştır. Daha sonra seçilen özüt tipleri 40 $\mathrm{mg} / \mathrm{ml}$ konsantrasyonda 48 süre ile hücre kültürü ortamına uygulanmıştır. Yapılan sayımlar ve analizler neticesinde Şekil 2'de $(a-c)$ verilen bulgular elde edilmiştir.

$\mathrm{Bu}$ veriler değerlendirildiğinde en iyi apoptotik etki $T$. terreum ve $T$. imbricatum mantarlarında gözlenmiştir. T. terreum etil asetat ve T. imbricatum metanol özütleri yüksek düzeyde apoptozise yol açmışlardır (Şekil 2a, 2c). T. terreum HL-60 hücre hattına karşı daha etkili bulunmuşken T. imbricatum MCF-7 hücre hattına karşı etkilidir. Ancak T. terreum etil asetat özütü uygulamasında apoptotik hücrelerin yanı sıra nekrotik hücreler de gözlenmiştir (Şekil 2a). Bu nedenle bu çalışma kapsamında en etkili bulunan mantar ve özüt tipi; T. imbricatum-metanol olarak belirlenmiştir.

\section{4-Tartişma ve Sonuç}

Kanserin bazı bileşikler kullanarak önlenmesi oldukça zor görünmektedir. Bu tip bileşiklerin kanserleşme sürecindeki değişiklikleri durdurması veya geri döndürmesi beklenmektedir. Günümüzde birçok yeni teknik kansere karşı aktif olabilecek yeni bileşiklerin moleküler ve biyokimyasal seviyede taranmasına olanak sağlamaktadır. Bu zamana kadar bu çalışmalar sayesinde çok sayıda yeni antikanser bileşik elde edilmiştir. Diğer taraftan tümör oluşumu ve metastazın moleküler temelleri ile ilgili ayrıntılı bilgi birikiminin yanı sıra çeşitli canlı gruplarında doğal olarak bulunan doğal bileşiklerin de bilinmesi kansere yol açan anormal moleküler ve biyokimyasal sinyalleri hedef alacak yeni ilaçların veya etken maddelerin keşfedilmesine olanak sağlamaktadır. Bu bakımdan çalışmam kapsamında ele alınan canlı grubu mantarlarla ilgili de çalışma ve bilgi birikimi bulunmaktadır. İnsanlar mantarları, mantar özütlerini veya mantarlardan elde edilen çeşitli ürünleri vücut savunma sisteminin ve insan sağllğının desteklenmesi amacıyla gıda takviyesi olarak veya beslenmelerinde kullandıkları görülmüştür. Mantarların antitümör aktivitesinin belirlenmesine yönelik araştırmalar mevcut olmakla birlikte bu çalışmalar mantarlarda bulunma olasılığ yükssek olan biyolojik olarak aktif birçok bileşiğin ortaya çıkarılmasını sağlayacaktır.

Son on yıl boyunca bu çalışma kapsamında da değerlendirilmiş olan Tricholoma genusuna ait farklı

26 | P a g e

www.iiste.org 
türlerden elde edilen mantar özütlerinin antiproliferatif aktiviteleri gösterilmiştir. Çalışmam kapsamında elde ettiğim veriler bu çalışmaların ışığında aşağıda ele alınmıştır.

Tricholoma türlerinden; başlangıçta bazı polisakkaritler veya polisakkarit-peptit kompleksleri elde edilmiştir ve bunların özellikle fare tümörlerindeki etkinlikleri çalışılmıştır. Bu çalışmalar in vivo olarak yürütülmüştür. Farelerde oluşturulan Sarkoma 180 tümörüne karşılık Tricholoma cinsi mantarların özütleri araştırılmıştır. T. lobayense, T. mongolicum ve T. giganteum mantarlarından elde edilen polisakkaritlerin ve/veya polisakkarit protein komplekslerinin farelerde bu tümör oluşumunu inhibe ettiğ bildirilmiştir (Mizuno vd., 1995, Wang vd., 1996, Liu vd., 1996). Sadece polisakkaritler ve protein kompleksleri değil aynı zamanda bazı Tricholoma türlerinden elde edilen lektinlerin de fare tümörleri üzerinde etkili olduğu gösterilmiştir (Wang vd., 1995, Li vd., 2008, Pena vd., 2009).

Devamında T. lobayense mantarına ait polisakkaritler veya polisakkarit-peptit komplekslerinin ras aracılığıyla yürütülen sinyalizasyon yolunu etkiledikleri ve antikanser etkilerini bu şekilde gösterdikleri sonucuna varılmıştır (Hsiao vd., 2004). Ras protein ailesi hücre biyolojisinin her alanında son derece kritik roller üstlenerek, hücrelerin bölünmesini, farklılaşmasını, hücre içi protein trafiğini (taşınmasını), hücre iskeletinin organizasyonunu, büyüme faktörü sinyal iletimini ve gen ifadesini düzenlemektedir. Bu bakımdan ras onkoproteininin düzenlenmesi kanserdeki önemli hedeflerden bir tanesidir.

T. mongolicum'dan elde edilen yeni bir lakkaz karaciğer (HepG2) ve meme (MCF-7) kanserlerinin hücre hatlarına karşı 0,3-5 $\mu \mathrm{M}$ aralığında hücrelerin bölünmelerini \%8-92 aralığında inhibe etmiştir (Miao vd., 2010). T. equestre'den elde edilen “flavomannin-6,6-dimethylether" bileşiği insan kolon kanseri hücreleri Caco-2 hücrelerinin bölünmelerini 90-112 g/ml konsantrasyon aralığında \%50-80 düzeylerinde inhibe etmiştir. Bu bileşik etkisini sitostatik olarak göstermiştir ve hücreleri G0/G1 fazında tutmuştur (Pena vd., 2009). T. matsutake'den elde edilen polisakkaritler ise HepG2 (Karaciğer) ve A549 (Akciğer) kanser hücre hatlarını inhibe etmiştir (You vd., 2013). T. terreum isimli mantarın meyvelerinden "terreumols" diye adlandırılan 4 adet yeni terpenoid elde edilmiştir. Bunların sitotoksik aktiviteleri 5 adet insan kanser hücre hattında çalışılmıştır ve etkileri cisplatin isimli kemoterapik ajan ile karşılaştırılmıştır. MCF-7 meme, SMMC-7721 karaciğer, HL-60 miyeloid lösemi, SW-480 kolon ve A-549 akciğer kanserlerine ait hücre hatları üzerinde $0,0625-40 \mu \mathrm{M}$ aralığında özellikle akciğer, meme ve kolon kanseri hücrelerinde pozitif kontrol olarak kullanılan cisplatin kadar etkili bulmuşlardır (Yin vd., 2013). Yapılan bu çalışmalardan anlaşılacağı üzere Tricholoma türleri hücre döngüsünü baskılayabilecek bazı bileşikler içermektedirler ve bu bileşiklerden bazıları da bilinen kemoterapik ajanlar ile yarışabilecek potansiyel antikanser aktiviteye sahiptirler. Etkilerini ise hücre döngüsünü durdurarak ortaya koymaktadırlar. Kontrolsüz veya durdurulamayan hücre döngüsünün kanser ile mücadele direkt hedef olduğu göz önünde bulundurulduğunda bu mantarların önemli aktif bileşikler içerdikleri görülmektedir. Özellikle T.terreum isimli türden elde edilen terpenoidler iyi düzeyde aktivite göstermişlerdir ve bu çalışma kapsamında değerlendirilen HL-60 ve MCF-7 hücre hatları ortak olarak kullanılmıştır. Yin vd. (2013) tarafından yapılan çalışmada terpenodiler 1:1 oranında kloroform:metanol çözücüleri kullanılarak elde edilmiştir. Yani polaritesi yüksek ve düşük çözücüler birlikte kullanılmıştır. Mevcut çalışma kapsamında bakıldığında etkili bulunan özüt tipi etil asetat özütü olmuştur (Şekil 1a). Bu bakımdan ele alındığında etil asetat polar bir çözücü olmakla birlikte dielektrik sabitesi düşüktür. Yani etken bileşikler çok yüksek polaritelerde ortaya çıkmamaktadır. Diğer taraftan verilerimde bu mantarın etil asetat özütünün HL-60 hücre hattında daha etkili olduğu bulunmuştur. Ancak MCF-7 hücre hattında da yüksek konsantrasyonda etkilidir. Yin vd. (2013)'ün yapmış olduğu çalışmada ise elde edilen terpenodiler akciğer, meme ve kolon kanserleri üzerinde etkili bulunmuştur. Tüm bunlar göz önünde bulundurulduğunda farklı fraksiyonlarda farklı bileşiklerin ortaya çıktığı ve etkinliklerinin değiştiği görülmektedir. Sonuçta bu mantar türünün özüt tipine bağlı olarak elde edilen bileşikler doğrultusunda etken maddeler ihtiva ettiği açıktır.

Araştırmam kapsamında çalıştığım diğer etkili tür T. imbricatum'dur. Bu türün metanol özütü etkilidir. T. imbricatum her iki hücre hattını da inhibe etmiştir. Metanol özütünün HL-60 hücre hattındaki $\mathrm{I}_{\mathrm{p}} \mathrm{C}_{50}$ değeri yaklaşık $30 \mathrm{mg} / \mathrm{ml}$ olarak hesaplanmıştır. MCF-7 hücre hattında da bu değer yaklaşık $30 \mathrm{mg} / \mathrm{ml}$ olarak belirlenmiştir (Şekil 1c). Literatürde göz önünde bulundurulduğunda proje kapsamında çalışılan mantarların kanser hücrelerine karşı aynı etkinliklere sahip olduğu ve onların bölünmelerini inhibe ettiği düşünülmektedir. Hücre döngüsünü durduracak biyolojik olarak aktif bileşikler içerdikleri sonuçlarla örtüşmektedir.

Apoptozis, çok hücreli bir organizmada embriyonik dönemden yaşlanmaya kadar devam eden süreçte birçok evrede yer alan önemli bir hücre ölüm yolağıdır. Embriyonik dönemde çeşitli yapıların oluşmasında veya DNA'sı ağır hasar gören ya da virüsle enfekte hücrelerin ölümünde temel rol oynar (Vaux ve Korsmeyer, 1999). Diğer bir önemli ölüm tipi olan nekroziste metabolik prosesler çok hızlıdır ve hasar ağırdır; hücre zarının geçirgenliği bozulur, hücre şişer ve zarın patlamasıyla hücre içindeki maddeler dışarı dağılır. Bunun aksine apoptoziste hücre zarının bütünlüğü bozulmaz (Kerr vd., 1980).

27 | P a g e

www.iiste.org 
Apoptozis; malignant veya kanser hücrelerini normal hücrelerden veya onları çevreleyen dokudan zarar vermeden uzaklaştırır. Apoptozisin çalışmasında aksaklık birç̧ok kanser tipinde yaygındır ve tedaviye karşı dirençlidir. Bu nedenle apoptozis yolakları kanser tedavisi için başlıca hedeflerdendir (Reed, 2003). Araştırmam kapsamında çalışılmış olan Tricholoma cinsi mantarlardan da apoptotik etki gösteren bileşikler izole edilmiştir. T. matsutake metanol özütünün HSC-2 insan oral kanserindeki etkileri araştırılmıştır. Yapılan bu çalışmada mantar özütünün hücrelerin bölünmesini inhibe ettiği ve apoptozisi uyardığı bulunmuştur. Apoptotik etki PARP enziminin artışılla gösterilmiştir ve bunun yanı sıra çekirdek yoğunlaşması ve fragmentasyonu da gözlenmiştir. Uygulanan özüt aynı zamanda Bak proteininin ekspresyonunu arttırmıştır (Shin vd., 2012). Diğer taraftan T. giganteum'dan elde edilen \%80'lik etanol özütünün Erlih asit tümörüne karşı etkinliği çalışılmıştır. Bu özütün apoptotik etki mekanizması çalışma kapsamında aydınlatılmıștır. Flow sitometre verilerine dayalı olarak uygulama sonucunda hücrelerin G0/G1 evresinde artış gösterdikleri ve G2/M evresinde azaldıkları gözlenmiştir. Bu veriler çalışma kapsamında apoptozise işaret etmektdir. Apoptozisin uyarılmış olabileceği aynı zamanda apoptotik hücrelerin morfolojik özellikleri de göz önünde bulundurularak çekirdek boyaları ile ortaya konmuştur. Çalışmada elde edilen verilere göre pro-apoptotik bir protein olan p53 proteinin seviyesi artış göstermiştir. Tüm bu sonuçlar Erlih asit tümöründe uygulama sonrasında apoptozisi işaret etmektedir. Burada $p 53$ aracılı̆̆ ile apoptozis başlatılmıştır ve bir diğer pro-apoptotik gen olan Bax'ın ekspresyonunda da artış meydana gelmiştir. Buna karşın anti-apoptotik bir protein olan Bcl- 2'de artış gözlenmemiştir (Chatterjee vd., 2013).

T. equestre'den elde edilen "flavomannin-6,6_-dimethylether" bileşiğinin etki mekanizmasının açıklandığı çalışmada insan kolon kanseri hücreleri Caco-2 kullanılmıştır. Bu bileşik etkisini sitostatik olarak göstermiştir ve hücreleri G0/G1 fazında tutmuştur. Bu veri p27 cdk inhibitör protein seviyelerindeki artış ile desteklenmiştir. Annexin-V ve DNA fragmentasyon verilerine dayalı olarak apoptotik ölümün gerçekleşmediği ortaya konmuştur. Ayrıca genotoksik etkisinin olmadığı da belirtilmiştir (Pena vd., 2009).

Çalışmalardan da görüldüğü üzere aynı cinse ait farklı mantar türlerinin bazıları oldukça iyi düzeyde apoptotik etki gösterirken bir diğeri apoptozis mekanizmasını çalıştıramamaktadır. Araştırmam kapsamında ele alınan türlerin etkili özütleri ile apoptozis denemeleri yapılmıştır ve benzer bir sonuca varılmıştır. Çalışılan türler arasında T.terreum ve T.imbricatum özütlerinin farklı hücre hatlarında farklı seviyelerde apoptozise yol açtı̆̆ görülmektedir. Buna karşın T.arvernense'den elde edilen özütün oldukça düşük seviyelerde bu mekanizma üzerinde etkili olduğu bulunmuştur (Şekil 2b). T.terreum etil asetat özütü uygulamasında apoptotik hücrelerin yanı sıra nekrotik hücrelerde gözlenmiştir ve HL-60 hücre hattında daha etkili bulunmuştur (Şekil 2a). Diğer taraftan T.imbricatum metanol özütü MCF-7 hücre hattında apoptozisi \%60 seviyesinde uyarmıştır (Şekil 2c). Literatür verilerine de bakıldığında araştırma kapsamında çalışılan farklı mantarların hem hücre hattı düzeyinde hem de apoptozis mekanizmalarını uyarma seviyelerinde farklılıkların olması içerdikleri etken maddeler ile bağlantılı bir sonuçtur.

Araştırma kapsamında çalışılmış olan T.terreum, T.arvernense ve T.imbricatum türlerinden elde edilen farklı özütler her iki hücre hattında $20-40 \mathrm{mg} / \mathrm{ml}$ konsantrasyon aralığında hücrelerin $\% 50$ 'sini inhibe etmiş̧tir. Bu özütler ile yapılan apoptozis araştırmalarında ise T.imbricatum metanol özütü MCF-7 hücre hattında $40 \mathrm{mg} / \mathrm{ml}$ konsantrasyonda $\% 60$ 'in üzerinde apoptotik hücre ölümüne yol açmıştır. Mevcut literatür incelendiğinde özellikle T.imbricatum türünden elde edilen verilerin bilim dünyası için yeni olduğu ve yapılacak olan yeni araştırmalara ışık tutacağı aşikardır.

\section{References}

Breene W.1990. Nutritional and medicinal value of speciality mushrooms. Journal of Food Production, 53: 883-894.

Chatterjee, S., Biswas, G., Chandra, S., Saha, G.K., Acharya, K. 2013. Apoptogenic effects of Tricholoma giganteum on Ehrlich's ascites carcinoma cell. Bioprocess Biosyst Eng., 36:101-107.

Ferreira, Isabel C.F.R., Barros, L., Abreu, R.M.V. 2009. Antioxidants in Wild Mushrooms. Current Medicinal Chemistry, 16(12):1543-1560.

Ganeshpurkar, A., Rai, G., Jain, A. P. 2010. Medicinal mushrooms: Towards a new horizon. Pharmacogn Rev., 4(8): 127-135.

Grusch, M., Polgar, D., Gfatter, S., Leuhuber, K., Huettenbrenner, S., Leisser, C., Fuhrmann, G., Kassie, F., Steinkellner, H., Smid, K., Peters, G.J., Jayaram, H.N., Klepal, W., Szekeres, T.,

28| P a g e

www.iiste.org 
Knasmüller, S., Krupitza, G. 2002. Maintenance of ATP favours apoptozis over necrosis triggered by benzamide riboside. Cell Death and Differentiation, 9:169-78.

Hosford, D., Pilz, D., Molina, R., Amaranthus, M. 1997. Ecology and managament of the commercically harvested american matsutake mushroom. General Technical Report, Portland, United States Department of Agriculture PNW- GTR- 412, 5-7.

Hsiao, W.L.W., Li, Y.Q., Lee, T.L., Li, N., You, M.M., Chang, S.T. 2004. Medicinal mushroom extracts inhibit ras-induced cell transformation and the inhibitory effect requires the presence of normal cells. Carcinogenesis. 25 (7), pp.1177-1183.

Huettenbrenner, S., Maier, S., Leisser, C., Polgar, D., Strasser, S., Grusch, M., Krupitza, G. 2003. The evolution of cell death programs as prerequisites of multicellularity. Mutation Research, 543(3):235-49.

Kerr, J.F.R., Wyllie, A.H., Currie, A.R. 1980. Cell death: the significance of apoptozis. Int Rev Cytol., 68:251-306

Li, Y.R., Liu, Q.H., Wang, H.X., Ng, T.B. 2008. A novel lectin with potent antitumor, mitogenic and HIV-1 reverse transcriptase inhibitory activities from the edible mushroom Pleurotus citrinopileatus. Biochim. Biophys. Acta. 1780 (1), 51- 57.

Lim, H.W., Yoon, J.H., Kim, Y.S., Lee, M.W., Park, S.Y., Choi, H.K. 2007. Free radical-scavenging and inhibition of nitric oxide production by four grades of pine mushroom (Tricholoma matsutake Sing.). Food Chemistry, 103, 1337-1342.

Liu, F., Ooi, V. E. C., Liu, W. K., Chang, S. T. 1996. Immunomodulation and Antitumor Activity of Polysaccharide-Protein Complex From the Culture Filtrates of a Local Edible Mushroom, Tricholoma lobayense. Gen. Pharmac. Vol. 27, No. 4, pp. 621-624.

Miao, L., Zhang, G., Wang, H., Ng, T. 2010. Purification and Characterization of a Laccase from the Edible Wild Mushroom Tricholoma mongolicum. J. Microbiol. Biotechnol. 20(7), 1069-1076.

Mizuno, T., Kinoshita, T., Zhuang, C., Ito, H., Mayuzumi, Y. 1995. Antitumor-active Heteroglycans from Niohshimeji Mushroom, Tricholoma giganteum. Biosci. Biotech. Biochem., 59(4), 568-571.

Pena-P.G., Reyes-Zurita, F.J., Deffieux, G., Azqueta, A., Lopez de Cerain, A., Centelles, J.J., Creppy, E.E., Cascante, M. 2009. Antiproliferative effect of flavomannin-6,6'-dimethylether from Tricholoma equestre on Caco-2 cells. Toxicology. 264, 192-197.

Reed, J.J. 2003. Holland-Frei Cancer Medicine; Ch 4, Edited by Donald W Kufe, Raphael E Pollock, Ralph R Weichselbaum, MD, Robert C Bast, Jr,Ted S Gansler, James F Holland and Emil Frei, III, 6th edt., BC Decker Inc ISBN: 1-55009-213-8.

Samanta, S., Maity, K., Nandi, A.K., Sen, I.K., Devi, S.P. Mukherjee, S., Maiti, T.K., Acharya, K., Islam, S.S. 2013. A glucan from an ectomycorrhizal edible mushroom Tricholoma crassum (Berk.) Sacc.: isolation, characterization, and biological studies. Carbohydrate Research, 367, 33 40 .

Shin, J.A., Kim, J.S., Hong, I.S., Cho, S.D. 2012. Bak is a key molecule in apoptozis induced by methanol extracts of Codonopsis lanceolata and Tricholoma matsutake in HSC-2 human oral cancer cells. Oncology Letters, 4: 1379-1383.

Vaux, D.L., Korsmeyer, S.J. 1999. Cell death in development. Cell, 96: 245-254.

Wang, H. X., Liu, W. K., Ng, T. B., Ooi, V. E. C., Chang, S. T. 1995. Immunomodulatory and Antitumor Activities of a Polysaccharide-Peptide Complex from a Mycelial Culture Of Tricholoma Sp., A Local Edible Mushroom. Life Sciences, Vol. 57, No. 3, pp. 269-281. 
Wang, H.X., Ng, T.B., Ooi, V.E., Liu, W.K., Chang, S.T. 1996. A polysaccharide-peptide complex from cultured mycelia of the mushroom Tricholoma mongolicum with immunoenhancing and antitumor activities. Biochem Cell Biol., 74(1):95-100.

Wang, C., Chen, Y., Hu, M., Ding, J., Xu, C., Wang, R. 2012. In vitro antioxidant activities of the polysaccharides from Tricholoma lobayense. International Journal of Biological Macromolecules, $50,534-539$.

Yin, X., Feng, T., Li, Z.H., Dong, Z.J., Li, Y., Liu, J.K. 2013. Highly Oxygenated Meroterpenoids from Fruiting Bodies of the Mushroom Tricholoma terreum. J. Nat. Prod., 76, 1365-1368.

You, L., Gao, Q., Feng, M., Yang, B., Ren, J., Gu, L., Cui, C., Zhao, M. 2013. Structural characterisation of polysaccharides from Tricholoma matsutake and their antioxidant and antitumour activities. Food Chemistry, 138, 2242-2249.

You, Q., Yin, X., Zhang, S., Jiang, Z. 2014. Extraction, purification, and antioxidant activities of polysaccharides from Tricholoma mongolicum Imai. Carbohydrate Polymers, 99, 1- 10. 